\title{
Cytotoxic Drugs Departments as a precondition for high-quality product
}

\section{Pracownia leku cytotoksycznego warunkiem wysokiej jakości produktu}

\author{
Katarzyna Głuszek \\ Holycross Cancer Centre, Kielce, Poland \\ Head of Centre: Stanisław Góźdź MD, PhD
}

Keys words: cytotoxic drugs, cancer, chemotherapy.

Słowa kluczowe: środki cytotoksyczne, nowotwory, chemioterapia.

\begin{abstract}
Cancer control is a tremendous challenge not only for the ill patient and physicians, but also for the whole health care system. For the first time, during the European Conference of Oncology Pharmacists, the highest standards of pharmaceutical care were proposed for cancer patients. Undoubtedly, the lifestyle and prophylaxis which would enable the detection of cancer at an early stage exert an effect on the development of the disease. Cytostatics show toxic, mutagenic, oncogenic and immunosuppressive effects; therefore, their preparation should be handled by the Central Cytotoxic Drugs Department, because the majority of the drugs prepared belong to Register A. Drugs are manufactured in accordance with GMP principles. All-Polish Standards adopted by the Polish Pharmaceutical Association delineate the direction to be developed by every hospital with respect to its own procedures and instructions. The Master of Pharmacy is responsible for the preparation of cytotoxic drugs. At one bench should work an operator and an assistant. The recommended working time should not exceed $2 \mathrm{~h}$ without break, and $5 \mathrm{~h}$ daily. The person who collects cytotoxic drugs from the Central Department should use a legible sign and a stamp including the hour and date of collection. While manufacturing cytostatics for patients in daily doses it is recommended to use concentrates in the form of solutions rather than lyophilised powders, which results in the shortening of the stage of production of the drug and reduces the possibility of forming aerosols; in the case of closed infusion systems (containers for infusion liquids) which are used for the production of daily doses, the cabinet should be equipped in two tight docks for dispensing. Needleless connection of the LUER-LOCK type - a recommendation of the ISOPP - guarantees a tight connection with the drug transfer port even in the case of an increase in pressure during the manufacture of drugs. To a certain extent a pharmacy becomes the producer and distributor of oncologic drugs. This is related with high requirements concerning the production of drugs (high quality), safety of the engaged staff, as well as participation in a rational management of medicines. According to the FIP, a pharmacy is a public health care facility where work is performed by authorised persons: Masters of Pharmacy and pharmacy technicians. At present the task of a clinical pharmacist also includes the supervision of activities in the area of clinical pharmacy. This is a new task for pharmacists, who are obliged to constantly expand their knowledge and actively participate in the activities of the medical team.
\end{abstract}

\section{Streszczenie}

Walka z nowotworami jest ogromnym wyzwaniem nie tylko dla chorego pacjenta, lekarzy, ale całego systemu opieki zdrowotnej. Po raz pierwszy na Europejskiej Konferencji Farmaceutów Onkologicznych zaproponowano najwyższe standardy opieki farmaceutycznej dla pacjentów z nowotworami. Niewątpliwie na powstawanie nowotworu ma wpływ styl życia oraz profilaktyka umożliwiająca wykrycie nowotworu we wczesnym stadium choroby. Ponieważ cytostatyki mają działanie toksyczne, mutagenne, onkogenne oraz immunosupresyjne, ich przygotowywaniem powinna zajmować się Centralna Pracownia Leku Cytotoksycznego, gdyż większość przygotowywanych leków należy do wykazu A. Leki są sporządzane według zasad GMP. Ogólnopolskie Standardy Zatwierdzone przez Polskie Towarzystwo Farmaceutyczne wyznaczają kierunek do opracowania przez każdy szpital własnych procedur i instrukcji. Za przygotowywanie leków cytotoksycznych odpowiada magister farmacji. Przy jednej loży powinien pracować operator i pomocnik. Zalecany czas pracy nie może przekraczać 2 godzin bez przerwy, a w ciągu dnia 5 godzin. Osoba odbierająca leki cytotoksyczne z Centralnej Pracowni podpisuje się czytelnym podpisem i pieczątką wraz z godziną i datą odbioru. Przy produkcji cytostatyków w dawkach dziennych dla pacjentów wskazane jest stosowanie koncentratów w postaci roztworów, a nie proszków liofilizowanych, powoduje to skrócenie etapu wykonania leku oraz zmniejsza możliwość powstawania aerozolu; natomiast w przypadku zamkniętych systemów infuzyjnych (pojemniki z płynami infuzyjnym), które są wykorzystywane do produkcji dawek dziennych, potrzebne są dwa szczelne porty do podawania. Bezigłowe połączenie typu LUER-LOCK - zalecenie ISOPP - gwarantuje szczelne połączenie z aparatem do przenoszenia leków nawet w przypadku wzrostu ciśnienia przy wykonywaniu leków. Apteka staje się 
poniekąd producentem oraz dystrybutorem leków onkologicznych. To nakłada się na wysokie wymagania co do produkcji leku (wysoka jakość), bezpieczeństwo osób wykonujących oraz udział w racjonalnym zarządzaniu lekami [10]. Według FIP apteka to placówka ochrony zdrowia publicznego, w której wykonują pracę osoby do tego uprawnione: magistrowie oraz technicy farmacji.

\section{Introduction}

At present, humanity is grappling with the greatest challenge - morbidity due to cancer and cancer-related mortality. It is noteworthy that every fourth inhabitant in the world dies due to cancer. Cancerous diseases are related with increased death rates, especially in the under $65 \mathrm{~s}$ [1]. Cancer control is a tremendous challenge, not only for the ill patients, but also for physicians and the whole health care system. Only a professional and multi-aspect approach to this problem would allow the implementation of an effective treatment that would be safe for patients and beneficial from an economic point of view. For the first time, during the European Conference of Oncology Pharmacy, the highest standards of pharmaceutical care were proposed for cancer patients [2, 3].

In recent years in Poland, the incidence of lung, colorectal and prostate cancer among males has remained on a constant level. Nevertheless, a growing tendency has been observed in the incidence of breast, colorectal and lung cancer in females. The highest mortality is related with lung cancer, both among males and females.

The factors which may contribute to the development of cancer are as follows: age, gender, diet, cigarette smoking, occupational factors, fertility rate, infections, sexual behaviours, alcohol consumption, environment pollution.

Undoubtedly, lifestyle and prophylaxis enabling the detection of cancer at an early stage exert an effect on the development of the disease [1].

\section{Methods of cancer treatment}

At present, the following techniques are applied in cancer treatment:

- Surgical treatment - radical or cytoreductive, is a local intervention related with perioperative pain.

- Radiotherapy - the method of treatment for types of cancer sensitive to radiation.

- Chemotherapy - the systemic treatment adjusted to the type of cancer and the stage of its advancement; but this brings about side effects and complications. This is the main method for the treatment of diffuse cancer, and supports the treatment of cancer with a limited-stage of metastasis.

- Immunotherapy - the method aimed at stimulation of the patient's immune system; however, undoubtedly the disadvantage of this method is the lack of the possibility to destroy a large number of cancer cells.

- Hormonal therapy - applied in the case of hormone-dependent cancers, and leads to the inhibition of cancer growth.
- Gene therapy - the latest method of treatment, which consists in the inactivation of oncogenes and activation of anticancer genes.

- Combined treatment $[4,5]$.

A distinct feature of cancer cells is their capability for creating metastatic foci, and uncontrolled growth, which is related with very intense cell division. Cytostatics do not act selectively, but attack rapidly dividing cells, including those which are normal, e.g. bone marrow, cells of the lymphatic system, epithelial cells or gametocytes.

Adequately adjusted chemotherapy considers the mechanisms of effect, pharmacokinetics, method, duration and frequency of use of cytostatics. Its goal is the prolongation of a patient's life. Therefore, the treatment of a cancerous disease should be started as early as possible, when the cells are most sensitive to chemotherapy. In the treatment, the highest tolerable doses of cytostatics are applied in combination and at time intervals, which conditions their higher effectiveness and lower immunosuppressiveness. Continuous treatment with lower doses is contraindicated. It is recommended to use drugs of different mechanisms of action and various undesirable effects. Polychemotherapy is aimed at destroying the largest possible number of cancer cells (so-called Skipper's concept), without simultaneous damage to healthy cells. The examination of concentrations of drugs in the patient's body allows the selection of the optimum treatment method.

Chronopharmacology considers the administration of drugs at specified times of the day, which affect the kinetics and action of cytostatic preparations, and consequently their effectiveness, and allows a reduction of side-effects.

Chemotherapy depends on the effect of drugs on the life cycle of a cell; therefore, cytostatic drugs may be divided as follows:

- independent;

- cell cycle-dependent - alkylating drugs and cytostatic antibiotics, except bleomycin;

- cell cycle phase dependent - antimetabolites, alkaloids, lignans ; hydroxycarbamide, procarbazine specific for the $\mathrm{S}$ phase, taxoids; bleomycin, irinotecan, amsacrine, mitoxantrone, topotecan, razoxane - specific for G2 phase; and asparaginase in G1 phase.

Generally, the drugs applied in cancer treatment may be divided as follows: alkylating drugs; antimetabolites of folic acid, purines, pyrimidines and nucleoside analogues; cytostatic antibiotics; alkaloids; taxoids; enzymes; hormones; other cytostatics [4]. 


\section{Cytotoxic Drugs Department}

The creation of Cytotoxic Drugs Departments in hospitals where there are oncology wards in which cytostatics are prepared in daily doses for individual patients, impose on a pharmacy an additional function and possibility for development. To a certain extent, a pharmacy becomes the producer and distributor of oncologic drugs. This is related with high requirements concerning the production of drugs (high quality), safety of the engaged staff, as well as participation in a rational management of medicines [10].

Cytostatics show toxic, mutagenic, oncogenic and immunosuppressive effects; therefore, their production should be handled by the Central Department for Cytotoxic Drugs. According to the Act of 6 September, 2001, Article 86, Clause 3, Point 3, the preparation of cytostatics in daily doses for patients should be performed by qualified pharmacists, whereas nurses are authorised for the administration of drugs (Act of 5 July, 1996). The preparation of a drug is a pharmaceutical service, which provides the sterility of the dug prepared, and even more so, that the majority of the prepared drugs are in the so-called Register of Class A drugs, which are strong-acting drugs, and are thus a task for pharmacists $[6,7]$.

Stages of organisation of work in a Cytotoxic Drugs Department:

1. A physician writes a prescription for an individual patient.

2. A pharmacist, after checking the prescription from the aspect of its content, formally begins the production process. This may be production with the use of adequate computer software.

3. Preparation of specified drugs (disinfection of the outer packages in the store room for preliminary disinfection).

4. In the room where the production takes place, in a laminar flow chamber, work a pharmacist (socalled operator) and an assistant (pharmaceutical technician).

5. After obtaining the drug, a label is printed for an individual patient containing information concerning storage, expiry date of the solution produced, and the diluent used for its production.

6. The drug is collected by a nurse and dispensed by a pharmacist.

Drugs are prepared in accordance with the good medical practice (GMP) principles, manufactured in specially adjusted rooms, which ensure not only the sterility of the preparations produced, but also the safety of the staff producing them. These are obviously sterile conditions, ensuring high quality of the manufactured drug. Information from the producer is considered, concerning the conditions of storage, storage durability and protection against light. The manufacture of a drug by a pharmacist is based on the drug characteristics chart and producer's information.
The All-Polish Standards adopted by the Polish Pharmaceutical Association delineate the direction of development by each hospital regarding their own procedures and instructions.

All these actions are based on the accepted instructions and procedures in written form, and all are supervised by qualified and trained staff. The manufacture of drugs is based on the following regulations: - Pharmaceutical Law Act of 6 September, 2001 (Journal of Laws of 2008, No. 45, Clause 271, with later amendments), Chapter 7, Article 86, Point 3.

- Quality Standards in Oncology Pharmacy, which have been accepted by the European Society of Oncology Pharmacy (ESOP, 2009), and the Standards ISOPP 2007 (Journal of Oncology Pharmacy Practice, Suppl. 13, 2007).

- Regulation by the Minister of Health in the matter of GMP principles (Good Manufacturing Practices) Journal of Laws of 2008, No. 184, Clause 1143.

The components of the Central Cytotoxic Drugs Department are:

- preliminary disinfection room, where disinfection is performed on packages of drugs used for production, which are supplied via a gate to a room with laminar chambers, where the production takes place;

- aseptic room with laminar chambers equipped with HEPA filters, with vertical air flow and a drop-down window, and a system of filters guaranteeing the maintenance of Class A purity, which is indispensable while manufacturing drugs. In each chamber a sub-pressure of approximately 200 Pascal (Pa) is required, whereas in the entire sterile cabinet the pressure is 15 Pascal greater, compared to other rooms. Chamber certification is necessary as an independent unit notified for work with cytotoxic substances. It ensures occupational safety, and contamination of the environment does not occur.

Exhaust air from the bench should be discharged into the external exhaust ventilation system. The ceiling of the aseptic part, where laminar chambers are placed, should be a supply ventilation system, also through HEPA filters, which guarantees Class B purity. Minimum air exchange is 20 -fold room volume per hour.

It is necessary to ensure proper levels of temperature and humidity - the scope of temperatures protecting against contamination and providing comfort for the staff is $18-22^{\circ} \mathrm{C}$, whereas adequate humidity preventing corrosion and condensation of water vapour ranges from 30-70\%. The principles of Good Manufacturing Practices specify the levels of microbiological contaminants (Journal of Laws of 2008, No. 184, Clause 1143):

- storage rooms for manufactured drugs - combining the material and aseptic parts by means of a gate;

- drug storage rooms equipped with pharmaceuticals and a temperature-monitoring refrigerator;

- gates between the aseptic room and the external environment. The doors should not be able to open si- 
multaneously due to an installed system of blockades. The pressure should be lower than in the room with laminar chambers. In the dirty part of the gate there should be a soap dispenser and place for left hospital clothes. The clean part should have a closet for storing sterile clothes and a disinfectant dispenser.

The staff who are manufacturing drugs (operator) and the assistant should be properly dressed in: protective apron; sterile gloves (two pairs); it is recommended that gloves should be changed every 30 minutes during the production, and after an apparent piercing or puncturing, in the case of taking hands out of the bench, the gloves should be changed; sterile mask; protective glasses;

It is not permitted to wear jewellery, tips, watches or make-up.

A prescription for a cytostatic drug in a daily dose for a patient should contain as the following:

- name of the ward or unit managing the treatment;

- number of patient's medical records and/or date of birth;

- body weight and/or body surface area;

- prescribed - in accordance with the INN names cytostatics (international or market name, therapeutic scheme);

- size of the dose based on laboratory tests and pharmacokinetic parameters;

- pharmaceutical form of the manufactured drug;

- volume and type of diluent;

- time of administration of the drug and the date of administration;

- date and signature of a physician (chemotherapist).

The prescription should be delivered before manufacture of the drug by a pharmacist. The order may also be made though computer software.

The task of a pharmacist is supplementation of the prescription obtained with: market name of the drug and its series number; name and series number of the diluent used; amount of drug, diluent; hour of manufacturing the preparation and name of the person who produced the drug; expiry date for the drug produced; name of employee who verified the prescription and name of the person who dispensed the drug.

The label of the drug produced should contain: patient's data - name, surname; date of birth or Personal Identification Number (PESEL); name of the ward; name of the drug, diluent, dose and drug volume of the solution produced; route and time of administration; conditions in which the drug should be stored; date and hour of manufacture of the drug; durability of the preparation produced.

The container with the cytotoxic drug and its external package should be properly labelled. This may be a sticker with the mark 'cytotoxic drug'; for appropriate printing, division of the drugs should be considered - into strong action drugs and the remaining pharmaceuticals.
Drugs prepared for transportation to the ward must be placed in plastic, tightly closed, thermostable containers. These containers may be returned to the Central Cytotoxic Drugs Department; however, only when sterilised. It is recommended that these have smooth surfaces and are easy to wash and disinfect. The transportation time should be the shortest and safest possible.

The master of pharmacy is responsible for the preparation of cytotoxic drugs. At one bench there should work an operator and an assistant. The recommended working time cannot exceed $2 \mathrm{~h}$ without a break, and 5 h daily.

The person collecting cytotoxic drugs from the Central Department should use a legible sign and a stamp, including the hour and date of collection.

Storage of cytotoxic drugs in a pharmacy must consider the division of these drugs into groups A and B, according to the provisions in Pharmacopoeia. They must be labelled as 'CYTOTOXIC'. Thermolabile drugs require a refrigerator with temperature monitoring.

While manufacturing cytostatics for patients in daily doses it is recommended to use concentrates in the form of solutions rather than lyophilised powders, which results in the shortening of the stage of production of the drug and reduces the possibility of forming aerosols. In the case of closed infusion systems (containers for infusion liquids) which are used for the production of daily doses, the cabinet should be equipped with two tight docks for dispensing. A licence for cytostatics is also required. As is known, a closed system protects against the escape of the drug and its vapour outside. Needleless connection of the LUER-LOCK type - recommended by the International Society of Oncology Pharmacy Practitioners (ISOPP) - guarantees a tight connection with the drug transfer port, even in the case of an increase in pressure during the manufacturing of drugs. If the therapy covers one cytostatic, it is administered in the form of a two-way system for chemotherapy, or, when this is a combination of several cytostatics, a multi-way system for chemotherapy is used. These sets guarantee the protection of both the patient and staff. The device on the line with a cytostatic should not have a vent, and even if it does - this vent must be closed.

The administration of a cytotoxic drug by a nurse covers firstly the filling with a neutral fluid of one or several lines (in the case of both two-way and multi-way sets), activation of the system (so-called vein washing), closing the port, and then opening the cannula containing the cytostatic drug. Termination of administration of the cytostatic is frequently followed by activation of the port with neutral fluids and vein washing [6].

According to the International Pharmaceutical Federation (FIP), a pharmacy is a public health care facility where work is performed by authorised persons: Masters of Pharmacy and pharmacy technicians. One of its tasks is the proper preparation of cytostatic 
drugs for individual patients and, therefore, the calculation of an individual dose, and primarily guaranteeing proper aseptic conditions while manufacturing the preparation. This guarantees safety for both the patient and the person producing the drug. Apart from this, the central performance of cytostatics exerts a favourable effect on hospital drug management (considering, for instance, loss of drugs and medical products). For this reason, pharmacists participate in the effective management of drugs in a hospital, and take part in the activities of the Therapeutic Committee. Also, the manufacturing of drugs in the Central Department results in the use of the full dose of the drug, because the production of drugs in the wards results in the full dose of the drug not being used, and consequently causes losses. It is obvious that the goal of the department is the effective use of drug resources in such a way that the losses are kept as low as possible. Cooperation between wards, as well as among the staff of the department, plays an important role. The sole act of gathering all orders from the wards of a hospital imposes rational drugs management, and not the constant generation of losses, as happens when drugs are produced by nurses in the wards $[5,10]$.

At present, the task of a hospital pharmacist is also the supervision of actions within the scope of clinical pharmacy, i.e.:

- counselling and supervision over drugs in the wards in selected nosologic units;

- monitoring of side effects of drugs, participation in multidisciplinary teams for the matters of pharmacology - so-called pharmacovigilance;

- participation in solving pharmacotherapeutic problems in clinical teams;

- participation in monitoring of clinical examinations; - pharmaceutical care widely implemented, not only in European countries but also worldwide [8].

It may be stated that there has been an increase in the number of clinical pharmacists who participate in pharmaceutical care and in the active life of a patient. In some cases, this is a clinical pharmacist who monitors and manages a patient in the process of treatment, even in the ambulatory care system. A clinical pharmacist is an integral component of care of a patient with a cancerous disease, starting drug therapy, providing the patient with information concerning the taking of the drug, its toxicity or interaction between medicines taken. Even the follow-up treatment may be subjected to further assessment by a pharmacist, whereas the first cycle is prescribed by a physician specialising in chemotherapy. Such a situation occured in a hospital in South Carolina, where the team of oncologists includes two physicians, three nurse practitioners and a clinical pharmacist. It could be said that a clinical pharmacist tries to reduce for a patient the effects of anti-cancer therapy - side effects, such as nausea or hair loss [2, 3].
It should be added that the task of a pharmacy is also the provision of preparations for parenteral feeding (as in the case of cytostatics) in daily doses for patients, as well as for enteral feeding, and preparations for haemodialysis, peritoneal dialysis and infusion fluids. In Pharmaceutical Law this is known as a pharmaceutical service [9]. The correct preparation begins in accordance to the principles of Good Manufacturing Practice (GMP). The final product must be sterile; therefore, it must be produced according to the relevant procedures in effect, which are related, among other things, with the presence of a bench with laminar air flow, which guarantees the sterility of the ready product and its apyrogenicity [6]. A hospital pharmacy is also engaged in clinical research carried out in a hospital, it participates in the selection of adequate pharmacotherapy and has an influence on the management of therapeutic preparations and medicinal products [9]. Thus, a hospital pharmacy and its pharmacists face new challenges, are obliged to constantly expand their knowledge and actively participate in the work of the medical environment.

\section{References}

1. Tuchowska P, Worach-Kardas H, Marcinkowski JT. Najczęstsze nowotwory złośliwe - główne czynniki ryzyka i możliwości optymalizacji działań profilaktycznych. Probl Hig Epidemiol 2013; 94: 166-71.

2. Sessions JK,Valgus J,Yowell Barbour S, et al. Role of oncology clinical pharmacists in light of the oncology workforce. Study J Oncol Pract 2010; 6: 270-2.

3. Geissler K. A shared fight against cancer: the complementary roles of oncology physicians and oncology pharmacists. Expert Rev Anticancer Ther 2013; 13; 13-5.

4. Janiec W, Krupińska J. Farmakodynamika. Podręcznik dla studentów farmacji. Wydawnictwo Lekarskie PZWL, Warsaw, 2002; 834-9.

5. Markowicz M, Szymański P, Mikiciuk-Olasik E. Zasady leczenia nowotworów. Radiologia i leczenie chirurgiczne. Aptekarz Polski 2009; 40/18 online.

6. Stanowisko konsultanta krajowego w dziedzinie pielęgniarstwa onkologicznego z dn. 10.01.2008.

7. Standardy jakościowe w farmacji onkologicznej” autorstwa Krystyny Chmal-Jagiełło, Hanny Jankowiak-Gracz, Hanny Kuźniar - zatwierdzone przez Europejskie Stowarzyszenie Farmaceutów Onkologicznych ESOP (01.2003).

8. Farmacja Szpitalna. Prof. dr hab. E.Grześkowiak Available at: http://www.mz.gov.pl/__data/assets/pdf_file/0020/ 7715/78_farmacja_szpitalna_13072011.pdf

9. Ustawa Prawo Farmaceutyczne z dn. 6.09.2001 Dz.U. nr 45 z 2008 poz. 271, rozdz. 7, art. 86.

10. Walczuk W. Oszczędności w szpitalu. Pracownia przygotowywania leków cytostatycznych. Czy to się opłaca? Farmacja Szpitalna 2010; 66.

\section{Address for correspondence:}

Katarzyna Głuszek

ul. Klonowa 5/4, 25-538 Kielce, Poland

Phone: +48413496909

E-mail: kasia.kielce@wp.pl 